\title{
A review of the Chaenostoma boscii species-complex (Decapoda: Brachyura: Macrophthalmidae) from the Indo-West Pacific
}

\author{
Shao-Jyun Teng, Hsi-Te Shih, Reza Naderloo, Laure Corbari
}

\begin{abstract}
The sentinel crabs, Chaenostoma orientale Stimpson, 1858, and C. crassimanus Stimpson, 1858, were both described from the Ryukyu Islands, Japan, and have both been long considered junior synonyms of $C$. boscii (Audouin, 1826). After examining specimens of the $C$. boscii species-complex from East Africa, the Malay Peninsula, Indonesia, New Caledonia, Papua New Guinea, the Philippines, Taiwan, and the Ryukyus, we now consider both $C$. crassimanus and $C$. orientale to be valid species, and C. lisae (Poupin \& Bouchard, 2010) is found to be a synonym of C. $\mathrm{cr}$ assimanus, based on the morphology of the carapace, male cheliped and male first gonopod, supported by molecular evidence from mitochondrial cytochrome oxidase subunit I (COI) sequences. Both $C$. orientale and $C$. crassimanus are found sympatrically in Taiwan (including Penghu), and possibly in the Ryukyus and New Caledonia. While $C$. boscii is endemic to the Red Sea, the distribution of $C$. sinuspersici is limited to the western Indian Ocean (East Africa and the Persian Gulf).
\end{abstract}

Key words: Chaenostoma orientale, C. crassimanus, C. lisae, C. boscii, C. sinuspersici, morphology, taxonomy, cytochrome oxidase subunit I

\section{Introduction}

Chaenostoma Stimpson, 1858, is a genus of small-sized (carapace width below $15 \mathrm{~mm}$ ) macrophthalmid crabs that inhabit tropical and subtropical rocky shores (Litulo, 2005; Davie, 2012). This genus for many years was considered to include only two species, C. boscii (Audouin, 1826) and C. punctulatus (Miers, 1884), but in recent years three new species have been added, viz., C. lisae (Poupin \& Bouchard, 2010), C. sinuspersici (Naderloo \& Türkay, 2011), and C. java Naderloo, 2013. Most recently, Shih et al. (2015), using morphological characters, reinstated two species previously considered junior synonyms of $C$. boscii, C. orientale Stimpson, 1858 and C. crassimanus Stimpson, 1858, and further suggested that $C$. lisae may be a synonym of $C$. crassimanus. As a result, the Chaenostoma boscii species-complex, used by $\mathrm{Ng}$ et al. (2008) and Naderloo \& Türkay (2011) for the taxonomic complexity of this group previously identified as $C$. boscii, includes $C$. boscii, $C$. crassimanus, C. java, C. lisae, C. orientale and C. sinuspersici.

Chaenostoma was originally established for C. orientale Stimpson, 1858, and C. crassimanus Stimpson, 1858, both from "Loo Choo" (= Ryukyu Islands or the Ryukyus) (Stimpson, 1858, 1907). Stimpson (1907) also considered Dana's (1852) record of "Cleistostoma boscii" from Fiji as $C$. orientale, while Macrophthalmus boscii Audouin, 1826 was treated within another genus Euplax H. Milne Edwards, 1852. Several authors (Milne-Edwards, 1873; Ortmann, 1894; Stebbing, 1910; Tesch, 1918) suggested that any morphological differences between C. orientale, C. crassimanus and Euplax boscii could simply be attributed to intraspecif- 
ic variation, and thus that all three species were synonymous. Thus, it followed that Stimpson's Chaenostoma had to be treated as a synonym of Euplax. Kemp (1919) stated he could find no clear difference between Euplax and Macrophthalmus sensu lato, and assigned $E$. boscii into Macrophthalmus, and this was followed by later authors until recently. Barnes (1967), as a part of his broader review studies of the genus, erected a subgenus Macrophthalmus (Mopsocarcinus) to include C. boscii and C. punctulatus. Later Chaenostoma was reinstated to replace Mopsocarcinus, because the latter is considered as a subjective junior synonym (Ng et al., 2001, 2008; Mendoza \& Ng, 2007; Barnes, 2010). Recently, Davie (2012) revised the Australian macrophthalmids and treated Chaenostoma as a full genus. Euplax was later synonymized under Macrophthalmus (Venitus) Barnes, 1967, by Barnes (1977), but is also now regarded as a good subgenus by Mendoza \& Ng (2007), or indeed possibly a good genus (see Kitaura et al., 2010; McLay et al., 2010). Nevertheless, its type species $E u$ plax leptophthalmus H. Milne Edwards, 1852, is clearly generically unrelated to the species of Chaenostoma treated here.

Chaenostoma boscii has long been considered to be widely distributed in the Indo-West Pacific (see Ng et al., 2008), however a recent study has shown that $C$. boscii is limited to its type locality, the Red Sea (Naderloo \& Türkay, 2011). Naderloo \& Türkay (2011) initially considered their new species $C$. sinuspersici (type locality: the Persian Gulf) to be widespread throughout the Indo-West Pacific, but Rahayu \& Nugroho (2012) suggested the specimens from the West Pacific needed to be re-examined and their status reassessed. Two additional species within this complex have now been described, viz. C. lisae (type locality: Mayotte), and C. java (type locality: Java).

Recently, the authors examined a series of specimens of this species-complex from numerous localities across the Indo-West Pacific, including the Red Sea, East Africa, the Malay Peninsula, Indonesia, New Caledonia, Papua New Guinea, the Philippines, Taiwan, and the Ryukyus. Among them, two species agreed with the description of $C$. orientale and $C$. $\mathrm{cr}$ assimanus, and therefore these species are here again recognized as distinct species (Stimpson, 1858, 1907; Shih et al., 2015). In addition, specimens of $C$. boscii, $C$. sinuspersici and $C$. lisae were also examined and this has enabled us for the first time to compare the morphology of all these nominal species, and to consider further molecular evidence from mitochondrial cytochrome oxidase subunit I (COI) sequences.

\section{Materials and Methods}

Specimens examined were from the Red Sea (Egypt and Saudi Arabia), East Africa (Madagascar, Mayotte, Kenya and Djibouti), Malay Peninsula (Tioman), Indonesia (Bali), New Caledonia, Papua New Guinea, the Philippines (Bohol), Taiwan (including Penghu), and the Ryukyus. These specimens are deposited in the following institutions: Zoological Collections of the Department of Life Science, National Chung Hsing University, Taichung, Taiwan (NCHUZOOL); Institute of Zoology, Academia Sinica, Taipei, Taiwan (ASIZ); Coastal Ecology laboratory, Biodiversity Research Center, Academia Sinica, Taipei, Taiwan (CEL); Museum National d'Histoire Naturelle, Paris, France (MNHN); National Museum of Marine Biology and Aquarium (NMMB); Department of Environmental Biology and Fisheries Science, National Taiwan Ocean University, Keelung, Taiwan (NTOU); Senckenberg Museum, Frankfurt am Main, Germany (SMF), and Lee Kong Chian Natural History Museum (formerly Raffles Museum of Biodiversity Research), National University of Singapore, Singapore (ZRC) (Table 1; Appendix 1). Specimens were illustrated with the help of a drawing tube attached to a stereomicroscope. G1 is an abbreviation for the male first gono- 
Table 1. The haplotypes of COI gene of the Chaenostoma boscii species-complex from the Indo-West Pacific, and the outgroups, used in this study. Abbreviations of museums or universities see Materials and Methods.

\begin{tabular}{|c|c|c|c|c|}
\hline Species & Locality & Catalogue no. & $\begin{array}{c}\text { Haplotype } \\
\text { of COI }\end{array}$ & $\begin{array}{c}\text { Access. no. } \\
\text { of COI }\end{array}$ \\
\hline \multirow[t]{16}{*}{ C. crassimanus } & Ryukyus, Japan: Okinawa & CEL-Oki-124 & $\mathrm{Cc} 1$ & LC155114 \\
\hline & Taiwan: Siaoliuciou, Pingtung & NCHUZOOL 13958 & $\mathrm{Cc} 1$ & LC155114 \\
\hline & Taiwan: Houwan, Pingtung & NCHUZOOL 13959 & $\mathrm{Cc} 4$ & LC155115 \\
\hline & Taiwan: Yingueibi, Pingtung & NCHUZOOL 13960 & $\mathrm{Cc} 1$ & LC155114 \\
\hline & Taiwan: Daguang, Pingtung & NCHUZOOL 13965 & $\mathrm{Cc} 2$ & LC155116 \\
\hline & Taiwan: Daguang, Pingtung & NCHUZOOL 13966 & $\mathrm{Cc} 1$ & LC155114 \\
\hline & Taiwan: Mudan, Pingtung & NCHUZOOL 13967 & $\mathrm{Cc} 1$ & LC155114 \\
\hline & Taiwan: Mudan, Pingtung & NCHUZOOL 13968 & $\mathrm{Cc} 3$ & LC155117 \\
\hline & Taiwan: Lyudao, Taitung & NTOU 20100528b & $\mathrm{Cc} 1$ & LC155114 \\
\hline & Taiwan: Fengguei, Penghu & NCHUZOOL 13972 & $\mathrm{Cc} 1$ & LC155114 \\
\hline & Taiwan: Fengguei, Penghu & NCHUZOOL 13972 & $\operatorname{Cc} 5$ & LC155118 \\
\hline & Taiwan: Wang-an, Penghu & NTOU 19900903 & Cc6 & LC155119 \\
\hline & New Caledonia: Noumea & MNHN-IU-2013-9292 & $\mathrm{Cc} 1$ & LC155114 \\
\hline & New Caledonia & MNHN-IU-2009-2591 & $\operatorname{Cc} 5$ & LC155118 \\
\hline & Mayotte (id. as C. lisae) & MNHN-IU-2009-993 & $\mathrm{Cc} 7$ & LC155120 \\
\hline & Mayotte (id. as C. lisae) & MNHN-IU-2009-993 & $\mathrm{Cc} 8$ & LC155121 \\
\hline \multirow[t]{9}{*}{ C. orientale } & Taiwan: Mao-ao, New Taipei City & NTOU 20070208 & Col & LC155122 \\
\hline & Taiwan: Hemei, New Taipei City & NTOU 20070421 & $\mathrm{Co} 2$ & LC155123 \\
\hline & Taiwan: Daguan, Pingtung & NCHUZOOL 13973 & $\mathrm{Co} 3$ & LC155124 \\
\hline & Taiwan: Fengguei, Penghu & NCHUZOOL 13975 & $\mathrm{Co} 4$ & LC155125 \\
\hline & Taiwan: Siyu, Penghu & NCHUZOOL 13982 & $\operatorname{Co} 5$ & LC097137 \\
\hline & Taiwan: Siyu, Penghu & NCHUZOOL 13980 & Co6 & LC155126 \\
\hline & Malaysia: Para Beach, Tioman & NCHUZOOL 13986 & $\mathrm{Co} 2$ & LC155123 \\
\hline & Indonesia: Nusa Dua, Bali & NCHUZOOL 13987 & $\mathrm{Co} 3$ & LC155124 \\
\hline & New Caledonia: Noumea & MNHN-IU-2013-9291 & $\mathrm{Co} 7$ & LC155127 \\
\hline \multirow[t]{2}{*}{ C. sinuspersici } & Iran: Gulf of Oman & NCHUZOOL 13988 & Cs1 & LC155128 \\
\hline & Mayotte & MNHN-IU-2009-992 & $\mathrm{Cs} 2$ & LC155129 \\
\hline C. boscii & Saudi Arabia: Farasan Islands & NCHUZOOL 13989 & $\mathrm{Cb} 1$ & LC155130 \\
\hline \multicolumn{5}{|l|}{ outgroups } \\
\hline Macrophthalmus banzai & Taiwan: Fangyuan, Changhua & NCHUZOOL 14807 & & LC155131 \\
\hline Macrophthalmus purpureocheir & Taiwan: Kenting, Pingtung & NMMB CDA890 & & LC097132 \\
\hline
\end{tabular}

pod. Measurements, in millimeters (mm), are of the carapace width $(\mathrm{CW})$.

Except Chaenostoma java, specimens of other species of the C. boscii species-complex were used in molecular study (Table 1). Genomic DNA was isolated from the muscle tissue of legs by using the GeneMark tissue and cell genomic DNA purification kit (Taichung, Taiwan). A portion of the COI gene was amplified with PCR using the primers LCO1490 (5'GGT CAACAAATCATAAAGATATTG G-3'), HCO2198 (5'-TAAACTTCAGGGTGACCAAAA AATCA-3') (Folmer et al., 1994), and COH6 (5'TADACTTCD GGR TGD CCAAARAAYCA-3')
(Schubart \& Huber, 2006). The PCR conditions for the above primers were denaturation for 50 $\mathrm{s}$ at $94^{\circ} \mathrm{C}$, annealing for $70 \mathrm{~s}$ at $45-47^{\circ} \mathrm{C}$, and extension for $60 \mathrm{~s}$ at $72^{\circ} \mathrm{C}$ (40 cycles), followed by extension for $10 \mathrm{~min}$ at $72^{\circ} \mathrm{C}$. Sequences were obtained by automated sequencing (Applied Biosystems 3730) and were aligned manually, after verification with the complementary strand. Macrophthalmus banzai Wada \& Sakai, 1989 and M. purpureocheir Teng \& Shih, 2015 were used as outgroups. Sequences of the different haplotypes were deposited in the DNA Data Bank of Japan (DDBJ), and the accession numbers are given 
in Table 1. Maximum likelihood (ML) analysis was conducted in RAxML (v. 7.2.6, Stamatakis, 2006), with the model GTR $+\mathrm{G}$ (i.e. GTRGAMMA) and 100 runs, and found the best ML tree by comparing the likelihood scores. The robustness of the ML tree was evaluated by 1000 bootstrap pseudoreplicates under the model GTRGAMMA. The Kimura (1980) 2-parameter distance (K2P distance) between haplotypes was calculated by the software MEGA 5 (Tamura et al., 2011).

\section{$\square$ Results}

\section{Morphological comparison}

The five species of the Chaenostoma boscii species-complex can be distinguished by a suite of morphological characters (Table 2; Fig. $1)$. The most reliable features include the direction of the first anterolateral tooth (= external orbital tooth), the depth and shape of the incision between the anterolateral teeth, the shape of the dactylar tooth of the cheliped and presence and extent of a setal patch in the cheliped gape, and the shape of the G1 (Table 2).

The specimens from Mayotte and Madagascar deposited in MNHN and identified as $C$. lisae (Table 1; Appendix 1) were also compared, but no significant morphological difference could be found to separate $C$. lisae from $C$. $\mathrm{cr}$ assimanus (Table 2; Fig. 1). The morphology of $C$. crassimanus is very different from other members of the species-complex, especially by the shape of the chelipeds, and the position and shape of large tooth on the dactylus of the male cheliped (see Table 2; Fig. 1).

Chaenostoma orientale, C. boscii and C. sinuspersici are similar in their slender chela morphology (palm length to fixed finger ratio of 1.5-2.0), but can be distinguished by the position and shape of the first and second anterolateral teeth, and their G1 morphology (Table 2; Fig. 1).

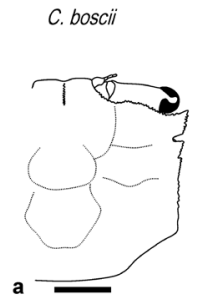

C. sinuspersici
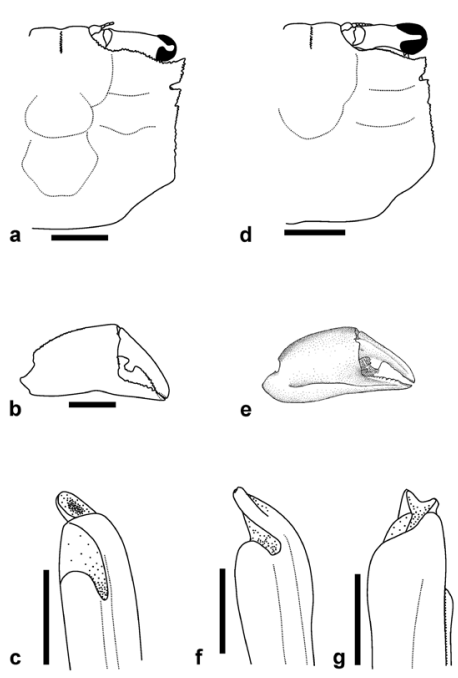

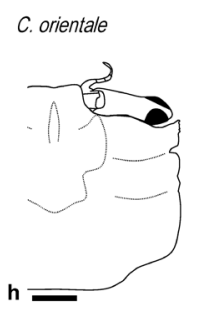

I

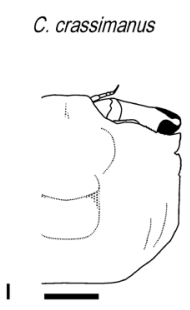

"C. lisae"

C. java
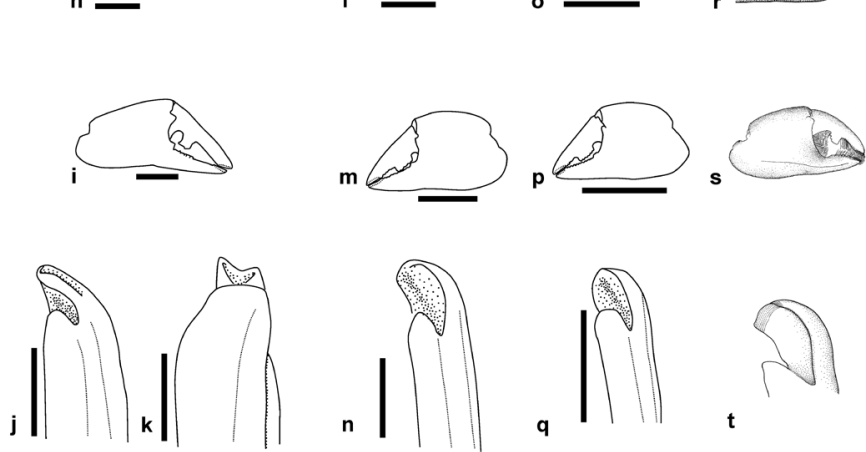

Fig. 1. a-c: Chaenostoma boscii (Audouin, 1826), ฮె (NCHUZOOL 13989), CW 8.8 mm. d-g: C. sinuspersici (Naderloo \& Türkay, 2011), d, f, g: సౌ (NCHUZOOL 13988), CW 7.5 mm; e: after Naderloo \& Türkay (2011). h-k: C. orientale Stimpson, 1858, ๙ (NCHUZOOL 13981), 12.3 mm. 1-n: C. crassimanus Stimpson, 1858, ð (NCHUZOOL 13968), CW 8.0 mm. o-q: "C. lisae" (=C. crassimanus), శౌ (MNHN-IU-2009-2591), CW 6.1 mm. r-t: C. java Naderloo, 2013, after Naderloo (2013). a, d, h, 1, o, r: carapace; b, e, i, s: right cheliped; $\mathrm{m}$, p: left cheliped; c, f, j, n, q, t: ventral view of G1; g, k: mesial view of G1. Scale bars $=2$ mm (a, $\mathrm{b}, \mathrm{d}, \mathrm{h}, \mathrm{i}, \mathrm{l}, \mathrm{m}, \mathrm{o}, \mathrm{p})$ and $0.5 \mathrm{~mm}(\mathrm{c}, \mathrm{f}, \mathrm{g}, \mathrm{j}, \mathrm{k}, \mathrm{n}, \mathrm{q})$. 
Table 2. Morphological comparison among five species of the Chaenostoma boscii species-complex.

\begin{tabular}{|c|c|c|c|c|c|c|}
\hline & & C. boscii & C. sinuspersici & C. orientale & C. crassimanus & C. java \\
\hline \multirow[t]{4}{*}{ carapace } & $\begin{array}{l}\text { 1st anterolateral } \\
\text { tooth } \\
\text { incision between } \\
1 \text { st and } 2 \text { nd } \\
\text { teeth }\end{array}$ & $\begin{array}{l}\text { protruding } \\
\text { anteriorly } \\
\text { deep }\end{array}$ & $\begin{array}{l}\text { protruding } \\
\text { anteriorly } \\
\text { deep }\end{array}$ & $\begin{array}{l}\text { protruding } \\
\text { anteriorly } \\
\text { deep }\end{array}$ & $\begin{array}{l}\text { protruding } \\
\text { laterally } \\
\text { shallow }\end{array}$ & $\begin{array}{l}\text { protruding } \\
\text { anteriorly } \\
\text { shallow }\end{array}$ \\
\hline & $\begin{array}{l}\text { extent of lateral } \\
\text { protrusion of } \\
\text { anterolateral } \\
\text { teeth }\end{array}$ & $\begin{array}{l}\text { 1st tooth } \\
\text { extending } \\
\text { far beyond } \\
\text { 2nd tooth }\end{array}$ & $\begin{array}{l}\text { tips of both teeth } \\
\text { having same } \\
\text { extent }\end{array}$ & $\begin{array}{l}\text { 1st tooth } \\
\text { extending } \\
\text { slightly } \\
\text { beyond 2nd } \\
\text { tooth }\end{array}$ & $\begin{array}{l}\text { tips of both teeth } \\
\text { having same } \\
\text { extent }\end{array}$ & $\begin{array}{l}\text { 2nd tooth } \\
\text { extending } \\
\text { slightly } \\
\text { beyond 1st } \\
\text { tooth }\end{array}$ \\
\hline & $\begin{array}{l}\text { posterolateral } \\
\text { margin }\end{array}$ & $\begin{array}{l}\text { slightly } \\
\text { converging } \\
\text { posteriorly }\end{array}$ & $\begin{array}{l}\text { straight, with the } \\
\text { same position } \\
\text { of margins of } \\
\text { anterolateral } \\
\text { teeth }\end{array}$ & $\begin{array}{l}\text { straight, less than } \\
\text { the margins of } \\
\text { anterolateral } \\
\text { teeth }\end{array}$ & $\begin{array}{l}\text { straight, with the } \\
\text { same position } \\
\text { of margins of } \\
\text { anterolateral } \\
\text { teeth }\end{array}$ & $\begin{array}{l}\text { diverging } \\
\text { posteriorly }\end{array}$ \\
\hline & frontal margin & concave & concave & concave & convex & concave \\
\hline $\begin{array}{l}\text { third } \\
\text { maxilliped }\end{array}$ & $\begin{array}{l}\text { length ratio } \\
\text { of ischium: } \\
\text { merus }\end{array}$ & 1.5 & 1.3 & $1.4-1.5$ & $1.2-1.3$ & 2.0 \\
\hline \multirow[t]{4}{*}{ cheliped } & $\begin{array}{l}\text { large tooth on } \\
\text { cutting margin } \\
\text { of dactylus }\end{array}$ & $\begin{array}{c}\text { subquadrate, } \\
\text { proximal }\end{array}$ & $\begin{array}{c}\text { subquadrate, } \\
\text { proximal }\end{array}$ & $\begin{array}{c}\text { subquadrate, } \\
\text { proximal }\end{array}$ & $\begin{array}{l}\text { low wide } \\
\text { rectangular, } \\
\text { middle }\end{array}$ & $\begin{array}{l}\text { subquadrate, } \\
\text { middle }\end{array}$ \\
\hline & shape of palm & slender & slender & slender & globular & globular \\
\hline & $\begin{array}{l}\text { extent of setal } \\
\text { patch on inner } \\
\text { face of palm }\end{array}$ & $\begin{array}{l}\text { both palm and } \\
\text { fingers }\end{array}$ & $\begin{array}{l}\text { both palm and } \\
\text { fingers }\end{array}$ & $\begin{array}{l}\text { both palm and } \\
\text { fingers }\end{array}$ & only palm & $\begin{array}{l}\text { both palm and } \\
\text { fingers }\end{array}$ \\
\hline & $\begin{array}{l}\text { stridulating } \\
\text { ridge on inner } \\
\text { merus }\end{array}$ & absent & present & present & absent & absent \\
\hline G1 & apical part & $\begin{array}{c}\text { plate-shaped, } \\
\text { quadrate }\end{array}$ & $\begin{array}{l}\text { mesial surface } \\
\text { of apical } \\
\text { part deeply } \\
\text { depressed, } \\
\text { from the top } \\
\text { of apical part } \\
\text { to chitinous } \\
\text { process }\end{array}$ & $\begin{array}{l}\text { mesial surface } \\
\text { of apical } \\
\text { part deeply } \\
\text { depressed, } \\
\text { only on } \\
\text { chitinous } \\
\text { process }\end{array}$ & $\begin{array}{l}\text { apical chitinous } \\
\text { process } \\
\text { short, with } \\
\text { distal margin } \\
\text { slightly } \\
\text { rounded }\end{array}$ & $\begin{array}{l}\text { lateral surface of } \\
\text { apical process } \\
\text { distinctly } \\
\text { depressed, } \\
\text { concave on } \\
\text { apical surface }\end{array}$ \\
\hline
\end{tabular}

\section{DNA analyses}

A 658-bp segment of COI from 17 specimens of $C$. crassimanus (including specimens identified as "C. lisae"), 11 specimens of $C$. orientale, 2 specimens of $C$. sinuspersici and 1 specimen of $C$. boscii was amplified, resulting in 8, 7, 2 and 1 different haplotypes, respectively (Table 1). According to the phylogenetic tree constructed by COI (Fig. 2), the haplotypes of C. orientale, $C$. sinuspersici and C. boscii form a clade, and the haplotypes of $C$. crassimanus form another clade, but the support value for the relationship between the two clades is weak $(66 \%)$. The nucleotide divergences with the $\mathrm{K} 2 \mathrm{P}$ distance within and between species are shown in Table 3. With regard to C. crassima$n u s$, although the intraspecific nucleotide divergence is relatively large $(\leq 0.92 \%)$, there are no natural subgroupings (Fig. 2) that might suggest more than one species, and otherwise, 


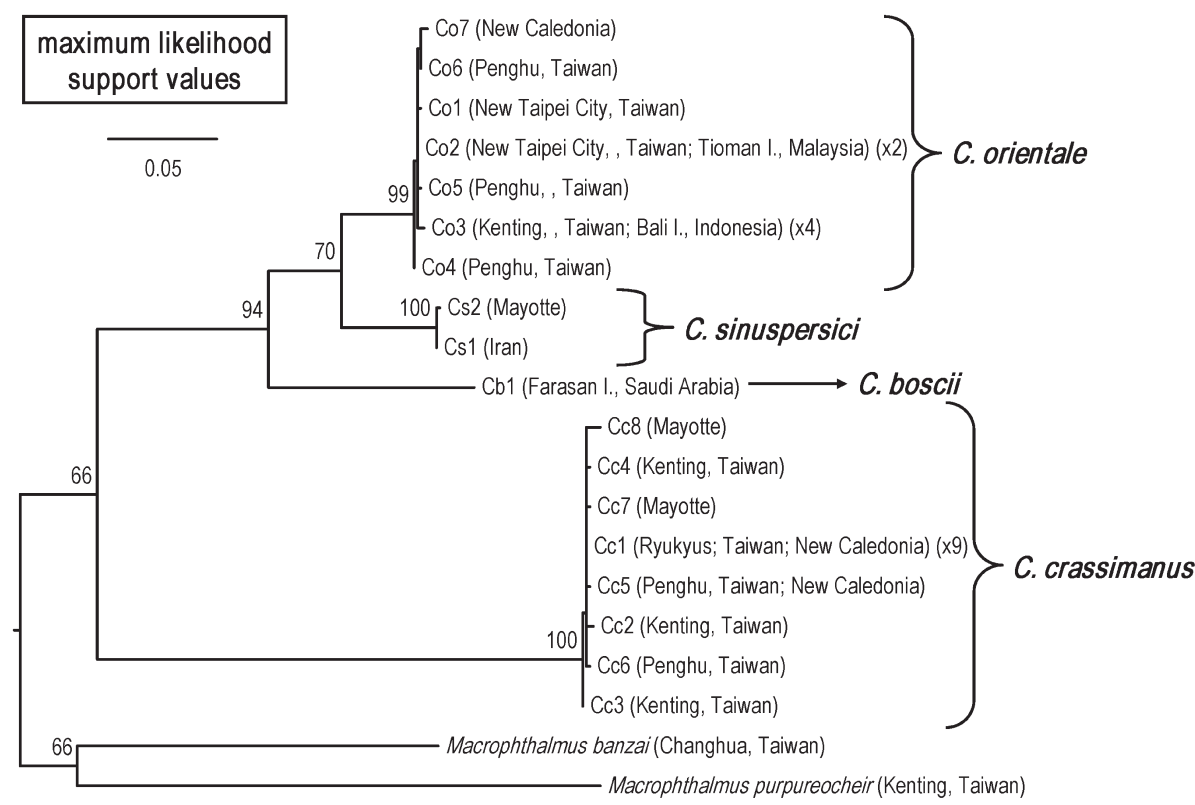

Fig. 2. A maximum likelihood tree of four species of the Chaenostoma boscii species-complex, based on the cytochrome oxidase subunit I (COI) gene. See Table 1 for details of the specimens. Probability values at the nodes represent support values for maximum likelihood.

Table 3. Matrix of percentage pairwise nucleotide divergences with K2P distance (lower left) and mean number of differences (upper right) based on 658 bp of COI within and between species of the Chaenostoma boscii species-complex. Values of range are shown in parentheses.

\begin{tabular}{|c|c|c|c|c|c|c|}
\hline & \multicolumn{2}{|c|}{ Intraspecific } & \multicolumn{4}{|c|}{ Interspecific } \\
\hline & $\begin{array}{l}\text { Nucleotide } \\
\text { divergence }\end{array}$ & $\begin{array}{l}\text { Mean nucleotide } \\
\text { difference }\end{array}$ & C. crassimanus & C. orientale & C. sinuspersici & C. boscii \\
\hline $\begin{array}{l}\text { C. crassimanus } \\
\text { (incl. "C. lisae") }\end{array}$ & $\begin{array}{c}0.21 \\
(0-0.92)\end{array}$ & $\begin{array}{c}1.4 \\
(0-6)\end{array}$ & - & $\begin{array}{c}108.65 \\
(104-112)\end{array}$ & $\begin{array}{c}111.97 \\
(110-116)\end{array}$ & $\begin{array}{c}109.07 \\
(108-110)\end{array}$ \\
\hline C. orientale & $\begin{array}{c}0.34 \\
(0-0.76)\end{array}$ & $\begin{array}{l}2.25 \\
(0-5)\end{array}$ & $\begin{array}{c}18.85 \\
(17.91-19.54)\end{array}$ & - & $\begin{array}{c}41.05 \\
(38-43)\end{array}$ & $\begin{array}{c}71.64 \\
(70-73)\end{array}$ \\
\hline C. sinuspersici & 0.15 & 1 & $\begin{array}{c}19.52 \\
(19.12-20.38)\end{array}$ & $\begin{array}{c}6.58 \\
(6.06-6.91)\end{array}$ & - & $\begin{array}{c}75.5 \\
(75-76)\end{array}$ \\
\hline C. boscii & - & - & $\begin{array}{c}18.93 \\
(18.71-19.12)\end{array}$ & $\begin{array}{c}12.07 \\
(11.76-12.31)\end{array}$ & $\begin{array}{c}12.79 \\
(12.7-12.89)\end{array}$ & - \\
\hline
\end{tabular}

the smallest interspecific divergence values within this species-complex are at least $6.06 \%$ (Table 3). The largest interspecific divergences occur between $C$. crassimanus and either $C$. orientale or $C$. sinuspersici $(\geq 17.91 \%$ and $\geq 19.12 \%$ respectively) (Table 3 ), but while $C$. crassimanus forms a separate monotypic clade (reflected in morphology: Table 2; Fig. 1), the genetic support value between the two clades is weak (Fig. 2).

\section{$\square$ Discussion}

The synonymy of $C$. lisae under $C$. crassimanus was suggested in Shih et al. (2015), and this study supports that action (Table 2; Fig. 1). Although most of the East African specimens tend to be smaller, the largest female reported 
has a CW of $9.1 \mathrm{~mm}$ (Poupin \& Bouchard, 2010: 62), which is similar in size to the largest specimens of $C$. crassimanus that we examined from the West Pacific (see Appendix 1). Molecular evidence (Table 3; Fig. 2) also supports C. lisae as a junior synonym of $C$. crassimanus (see below).

The smallest interspecific COI divergence value between species in this complex $(\geq 6.06 \%$ ) (Table 3 ), is larger than that between other closely related intertidal crab species, e.g. 2.49\% between Uca splendida (Stimpson, 1858) and U. crassipes (White, 1847) (Shih et al., 2012); 3.62\% between Mictyris guinotae Davie, Shih \& Chan, 2010 and M. brevidactylus Stimpson, 1858 (Davie et al., 2010); 4.1\% for the Sesarma reticulatum (Say, 1817) group (Schubart et al., 1998); 4.43\% between Scopimera ryukyuensis Wong, Chan \& Shih, 2010 and S. globosa De Haan, 1835 (Wong et al., 2010); 4.74\% between Helice tridens (De Haan, 1835) and the H. latimera Parisi, 1918 clade (Shih \& Suzuki, 2008); and $4.77 \%$ between Uca jocelynae Shih, Naruse \& Ng, 2010 and U. neocultrimana (Bott, 1973) (Shih et al., 2010). Thus the degree of COI divergence convincingly supports the recognition of $C$. crassimanus, $C$. orientale, $C$. sinuspersici and $C$. boscii as different species, but does not support C. lisae as separate from C. crassimanus.

Chaenostoma crassimanus and $C$. orientale are sympatric in some areas (see below), and similar in coloration (Shih et al., 2015), but can be easily separated using the morphological characters listed in Table 2 and Fig. 1. As previously mentioned, there is a deep phylogenetic split from the other species in the complex (Table 3; Fig. 2).

Chaenostoma java is close to C. boscii, $C$. orientale, and $C$. sinuspersici in the subquadrate and protruding tooth on the cutting edge of movable finger of male cheliped, and in the form of the first anterolateral tooth, but the male chela of C. java is not as slender as that of the above species (Table 2; Fig. 1r-t; Nader- loo, 2013: fig. 1).

Stimpson (1907) considered Dana's specimen from Fiji to be $C$. orientale, based on the morphology of its third maxillipeds. The chela and carapace shown in Dana's (1852) figures (pl. 19(3)) also suggest the Fijian specimen is close to $C$. orientale, however the margins of the sixth somite of the male abdomen of our specimens of $C$. orientale are more swollen centrally compared to Dana's specimen which appears to have straight lateral margins. The identity of Fijian specimens therefore still needs to be fully confirmed.

Barnes (1967) identified specimens from Australia (Queensland), New Caledonia, New Guinea and Solomon Islands (Santa Cruz Islands) as " $M$. boscil". The slender chelipeds of his samples would suggest they may be $C$. orientale, but the figures of the G1 and the male abdomen (Barnes, 1967: fig. 9) appear to differ from that species. Unfortunately, Barnes (1967) did not indicate the provenance of the specimen that he figured (Queensland is presumed but not certain), or for that matter, in what museum most of the specimens he examined are housed. It is possible that several species within the C. boscii species-complex (as presently conceived) were represented in the samples he examined. Davie (2012) similarly recorded $C$. boscii from numerous Queensland localities, apparently overlooking the review paper by Naderloo \& Türkay (2011) which described $C$. sinuspersici as the widespread species that occurred in Australia. Davie (2012) did not describe his specimens in detail, and did not figure the G1, so it is difficult to be sure of the identity of the Queensland species. The shape of the carapace margins and anterolateral teeth (Davie, 2012: fig. 38a, b) appear most similar to $C$. orientale, however the broad quadrangular palm of the male chela, and the shape of the basal tooth of the dactylus (Davie, 2012: fig. 38c; P. J. F. Davie, personal communication) are more like $C$. sinuspersici. The specimens examined by both Barnes (1967) and Davie 
(2012), particularly those from Australia, will need to be re-examined before their identity can be confirmed.

Two records of "Macrophthalmus boscii" from Japan were most likely based on misidentifications. Miyake (1983: 168) identified a female specimen form Ishigaki, the Ryukyus, as Macrophthalmus boscii, but based on the photograph (Miyake, 1983: pl. 56 (5)), it appears to have long eyestalks, a narrow front, and a clear second anterolateral tooth, and so is most probably a juvenile $M$. convexus. Takeda (1982) also recorded Macrophthalmus boscii from Japan, but the short eyestalks, the wide front, the shape of carapace, and the presence of only one anterolateral tooth (as shown by his unnumbered photograph on page 211) suggests it is more likely a varunid (either in Thalassograpsus or Baruna).

With regard to the distribution of the C. boscii species-complex group, C. boscii s. str. is limited to the Red Sea (Naderloo \& Türkay, 2011); C. sinuspersici ranges from the Persian Gulf to East Africa (Naderloo \& Türkay, 2011; this study); C. crassimanus is the most widelydistributed species, from East Africa to New Caledonia (Stimpson, 1858, 1907; Sakai, 1939; Chen, 1980; Poupin \& Bouchard, 2010; Poupin et al., 2012; Bouchard et al., 2013; Shih et al., 2015; this study); C. orientale also has wide distribution, between Phuket (Thailand) and Fiji, including Southeast Asia and East Asia (Stimpson, 1858, 1907; Dai et al., 1986; Dai \& Yang, 1991; Huang, 1992; Komai et al., 1995; Juncker \& Poupin, 2009; Rahayu \& Nugroho, 2012; Shih et al., 2015; this study); and C. java is so far only recorded from Java, Indonesia (Naderloo, 2013). There is still no study on the larval development of this group, however, the wide distribution of C. crassimanus is probably caused by longer larval development periods, as suggested for Cyclograpsus integer $\mathrm{H}$. Milne Edwards, 1837 (Gore \& Scotto, 1982).

Some species in the $C$. boscii speciescomplex occur sympatrically, e.g., C. orientale and $C$. crassimanus in southern Taiwan and Penghu, as well as possibly in the Ryukyus and New Caledonia; and $C$. sinuspersici and $C$. crassimanus in Mayotte and Madagascar (this study; Stimpson, 1858, 1907; Naderloo \& Türkay, 2011; Naderloo, 2013). However, it seems that $C$. orientale and $C$. crassimanus prefer different microhabitats. In Taiwan $C$. orientale prefers to hide under large stones with sandy sediment, while $C$. crassimanus likes to form burrows under reef rock into coarse sandy sediments in seagrass areas (SJT, personal observation). In southern Taiwan, $C$. orientale and C. crassimanus are also sympatric with Macrophthalmus purpureocheir (Shih et al., 2015; Teng \& Shih, 2015).

Although previous studies have suggested that $C$. sinuspersici is widely distributed in the Indo-West Pacific, our study shows that $C$. sinuspersici is limited to East Africa and the Persian Gulf. In contrast, both $C$. orientale and $C$. crassimanus are reinstated as distinct species on the strength of morphological and molecular evidence, with $C$. lisae being treated as a synonym of $C$. crassimanus. While C. crassima$n u s$ is widely distributed in Indo-West Pacific (reflected in the larger intraspecific COI variation), $C$. orientale is limited to the eastern Indian Ocean and the West Pacific.

\section{Acknowledgments}

This study was supported by grants from the National Science Council (NSC 101-2621-B005-001-MY3) and Ministry of Science and Technology (MOST 103-2621-B-005-001), Executive Yuan, Taiwan, to HTS. Special thanks to Peter K. L. Ng for discussing this research. Thanks are also due to Joseph Poupin, Michael Türkay, Ali M Al-Aidaroos, Paula Martin-Lefevre, Dwi Listyo Rahayu, YuHsi Wang, Jung-Hsiang Lee, Ping-Ho Ho, Ming-Shiou Jeng, Benny K. K. Chan, JhengJhang Li, Yi-Jia Shih and Jose Christopher E. Mendoza for providing specimens or locality 
information, to J. C. E. Mendoza for the comments on the earlier draft, and to the members of the HTS's laboratory for help undertaking the molecular work. We acknowledge Peter Davie who greatly improved this manuscript, as well as the comments from Tohru Naruse.

\section{Literature Cited}

Barnes, R. S. K., 1967. The Macrophthalminae of Australasia; with a review of the evolution and morphological diversity of the type genus Macrophthalmus (Crustacea: Brachyura). Transactions of the Zoological Society of London, 31: 195-161.

Barnes, R. S. K., 1977. Concluding contribution towards a revision, and a key to, the genus Macrophthalmus (Crustacea: Brachyura). Journal of Zoology, London, 182: 267-280.

Barnes, R. S. K., 2010. A review of the sentinel and allied crabs (Crustacea: Brachyura: Macrophthalmidae), with particular reference to the genus Macrophthalmus. Raffles Bulletin of Zoology, 58: 31-49.

Bouchard, J. M., Poupin, J., Cleva, R., Dumas, J., \& Dinhut, V., 2013. Land, mangrove and freshwater decapod crustaceans of Mayotte region (Crustacea Decapoda). Atoll Research Bulletin, 592: 1-60.

Chen, H.-L., 1980. Studies on the crabs of the Xisha Islands, Guangdong Province, China. II. Studia Marina Sinica, 17: 117-147, pls. IIV. (In Chinese)

Dai, A.-Y., \& Yang, S.-L., 1991. Crabs of the China Seas. $21+608$ pp., 74 pls. China Ocean Press, Beijing and Springer-Verlag, Berlin.

Dai, A.-Y., Yang, S.-L., Song, Y.-Z., \& Chen, G.X., 1986. Crabs of the China Seas. $17+568$ pp., 74 pls. China Ocean Press, Beijing. (In Chinese)

Dana J. D., 1852. Crustacea. In: United States Exploring Expedition during the Years 1838, $1839,1840,1841,1842$. Under the Command of Charles Wilkes, U.S.N., 13(2): iviii, 1-685.
Davie, P. J. F., 2012. A review of Macrophthalmus sensu lato (Crustacea: Decapoda: Macrophthalmidae) from Australia, including two new species and new records. Memoirs of the Queensland Museum, 56: 149-219.

Davie, P. J. F., Shih, H.-T., \& Chan, B. K. K., 2010. A new species of Mictyris (Decapoda, Brachyura, Mictyridae) from the Ryukyu Islands, Japan. Crustaceana Monographs, 11: 83-105.

Folmer, O., Black, M., Hoeh, W., Lutz, R., \& Vrijenhoek, R., 1994. DNA primers for amplification of mitochondrial cytochrome $\mathrm{c}$ oxidase subunit I from diverse metazoan invertebrates. Molecular Marine Biology and Biotechnology, 3: 294-299.

Gore, R. H., \& Scotto, L. E., 1982. Cyclograpsus integer H. Milne Edwards, 1837 (Brachyura, Grapsidae): the complete larval development in the laboratory, with notes on larvae of the genus Cyclograpsus. Fishery Bulletin, 80: 501-521.

Huang, J.-F., Yu, H.-P., \& Takeda, M., 1992. A review of the ocypodid and mictyrid crabs (Crustacea: Decapoda: Brachyura) in Taiwan. Bulletin of the Institute of Zoology, Academia Sinica, 31: 141-161.

Juncker, M., \& Poupin, J., 2009. Crustacés de Nouvelle-Calédonie. Illustration des espèces communes et liste documentée des espèces terrestres et des récifs. 77 pp., 33 pls. Rapport Scientifique du CRISP, Nouméa Cedex, Nouvelle-Calédonie.

Kemp, S., 1919. Notes on Crustacea Decapoda in the Indian Museum. xiii. The Indian species of Macrophthalmus. Records of the Indian Museum, 16: 383-394.

Kimura, M., 1980. A simple method for estimating evolutionary rates of base substitutions through comparative studies of nucleotide sequences. Journal of Molecular Evolution, 16: 111-120.

Kitaura, J., Wada, K., Fukui, Y. \& McLay, C. L., 2010. Molecular phylogenetic position of the New Zealand sentinel crab, Macrophthalmus (Hemiplax) hirtipes (Jacquinot, in 
Hombron \& Jacquinot, 1846) (Decapoda, Brachyura, Macrophthalmidae). Crustaceana, 83: 1315-1326.

Komai, T., Goshima, S., \& Murai, M., 1995. Crabs of the genus Macrophthalmus of Phuket, Thailand (Crustacea: Decapoda: Ocypodidae). Bulletin of Marine Science, 56: 103-149.

Litulo, C., 2005. Life history of the crab, Macrophthalmus boscii (Audouin, 1826) (Decapoda, Brachyura, Ocypodidae). Crustaceana, 78: 665-676.

McLay, C. L., Kitaura, J., \& Wada, K., 2010. Behavioural and molecular evidence for the systematic position of Macrophthalmus (Hemiplax) hirtipes Hombron \& Jacquinot, 1846, with comments on macrophthalmine subgenera (Decapoda, Brachyura, Macrophthalmidae). Studies on Malacostraca: Lipke Bijdeley Holthuis Memorial Volume. In: Fransen, C. H. J. M., De Grave, S. \& Ng, P. K. L., (eds.). Crustaceana Monographs, 14: 483-503.

Mendoza, J. C. E., \& Ng, P. K. L., 2007. Macrophthalmus (Euplax) H. Milne Edwards, 1852, a valid subgenus of ocypodoid crab (Decapoda: Brachyura: Macrophthalmidae), with description of a new species from the Philippines. Journal of Crustacean Biology, 27: 670-680.

Milne-Edwards, A., 1873. Recherches sur la faune carcinologique de la Nouvelle-Calédonie, II. Nouvelles Archives du Muséum d'Histoire Naturelle, 9: 155-332.

Miyake, S., 1983. Japanese Crustacean Decapods and Stomatopods in Color. vol. II: Brachyura (Crabs). 8+277 pp., 64 pls. Hoikusha Publishing Co., LTD., Osaka, Japan. (In Japanese)

Naderloo, R., 2013. The sentinel crabs of the genus Chaenostoma (Stimpson, 1858) (Crustacea: Brachyura: Macrophthalmidae), with description of a new species and new records. Journal of Natural History, 47: 28352848.

Naderloo, R., \& Türkay, M., 2011. A new species of the Macrophthalmus boscii-group (Decapoda: Brachyura: Macrophthalmidae) from the Persian Gulf with designation of a neotype for M. boscii Audouin (1826). Marine Biodiversity, 41: 503-515.

Ng, P. K. L., Guinot, D., \& Davie, P. J. F., 2008. Systema Brachyurorum: Part I. An annotated checklist of extant brachyuran crabs of the world. Raffles Bulletin of Zoology, Supplement, 17: 1-296.

Ng, P. K. L., Wang, C.-H., Ho, P.-H., \& Shih, H.-T., 2001. An annotated checklist of brachyuran crabs from Taiwan (Crustacea: Decapoda). National Taiwan Museum Special Publication Series, 11: 1-86.

Ortmann, A. E., 1894. Crustaceen. In: Semon, R. (ed.), Zoologische Forschungsreisen in Australien und dem malayischen Archipel. Denkschriften der Medicinisch-Naturwissenschaftlichen Geselschaft zu Jena, Verlag von Gusta Fischer, Jena, Germany, 8: 3-80.

Poupin, J., \& Bouchard, J. M., 2010. A new dwarf sentinel crab from Mayotte Island, western Indian Ocean (Decapoda: Brachyura: Macrophthalmidae). Zootaxa, 2501: 61-67.

Poupin, J., Zubia, M., Gravier-Bonnet, N., Chabanet, P., \& Malay, M., 2012. Illustrated checklist of the Decapoda at Europa Island. Western Indian Ocean Journal of Marine Science, 11: 1-25.

Rahayu, D. L., \& Nugroho, D. A., 2012. The Indonesian species of Macrophthalmus Desmarest, 1823, with the description of a new species (Crustacea: Decapoda: Brachyura: Macrophthalmidae). Zootaxa, 3158: 20-36.

Sakai, T., 1939. Studies on the Crabs of Japan. IV. Brachygnatha, Brachyrhyncha. vol. 3: 365-741.

Schubart, C. D., Diesel, R., \& Hedges, S. B., 1998. Rapid evolution to terrestrial life in Jamaican crabs. Nature, 393: 363-365.

Schubart, C. D., \& Huber, M. G. J., 2006. Genetic comparisons of German populations of the stone crayfish, Austropotamobius torrentium (Crustacea: Astacidae). Bulletin Français de 
la Pêche et de la Pisciculture, 380-381: 1019-1028.

Shih, H.-T., Chan, B. K. K., Teng, S.-J., \& Wong, K. J. H., 2015. Crustacean Fauna of Taiwan: Brachyuran Crabs, Vol II-Ocypodoidea. 320 pp. National Chung Hsing University, Taichung, Taiwan.

Shih, H.-T., Naruse, T., \& Ng, P. K. L., 2010. Uca jocelynae sp. nov., a new species of fiddler crab (Crustacea: Brachyura: Ocypodidae) from the western Pacific. Zootaxa, 2337: 47-62.

Shih, H.-T., Ng, P. K. L., Wong, K. J. H., \& Chan, B. K. K., 2012. Gelasimus splendidus Stimpson, 1858 (Crustacea: Brachyura: Ocypodidae), a valid species of fiddler crab from the northern South China Sea and Taiwan Strait. Zootaxa, 3490: 30-47.

Shih, H.-T., \& Suzuki, H., 2008. Taxonomy, phylogeny, and biogeography of the endemic mudflat crab Helice/Chasmagnathus complex (Crustacea: Brachyura: Varunidae) from East Asia. Zoological Studies, 47: $114-125$.

Stamatakis, A., 2006. RAxML-VI-HPC: Maximum likelihood-based phylogenetic analyses with thousands of taxa and mixed models. Bioinformatics, 22: 2688-2690.

Stebbing, R. T. R. R., 1910. General catalogue of South African Crustacea. (Part V of S. A. Crustacea, for the marine investigations in South Africa). Annals of the South African Museum, 6: 281-593.

Stimpson, W., 1858. Prodromus descriptionis animalium evertebratorum, quae in Expeditione ad Oceanum Pacificum Septentrionalem, a Republica Federata missa, Cadwaladaro Ringgold et Johanne Rodgers Ducibus, observavit et descripsit. Pars V. Crustacea Ocypodoidea. Proceedings of the Academy of Natural Sciences of Philadelphia, 10: 93110.

Stimpson, W., 1907. Report on the Crustacea (Brachyura and Anomura) collected by the North Pacific Exploring Expedition, 18531856. Smithsonian Miscellaneous Collec- tions, 49(1717): 1-240.

Takeda, M., 1982. Keys to the Japanese and Foreign Crustaceans Fully Illustrated in Colors. $58+284$ pp. Hokuryukan Ltd., Tokyo. (In Japanese)

Tamura, K., Peterson, D., Peterson, N., Stecher, G., Nei, M., \& Kumar, S., 2011. MEGA5: Molecular evolutionary genetics analysis using maximum likelihood, evolutionary distance, and maximum parsimony methods. Molecular Biology and Evolution, 28: 2731-2739.

Teng, S.-J., \& Shih, H.-T., 2015. A new species of Macrophthalmus Desmarest, 1823 (Crustacea: Decapoda: Brachyura: Macrophthalmidae) from Taiwan, with notes on four new records. Zootaxa, 4058: 451-470.

Tesch, J. J., 1918. The Decapoda Brachyura of the Siboga Expedition. I. Hymenosomidae, Retroplumidae, Ocypodidae, Grapsidae and Gecarcinidae. Siboga-Expeditie, 39(c): 1-148, pls. 1-6.

Wong, K. J., Chan, B. K. K., \& Shih, H.-T. 2010. Taxonomy of the sand bubbler crabs Scopimera globosa De Haan, 1835, and S. tuberculata Stimpson, 1858 (Crustacea: Decapoda: Dotillidae) in East Asia, with description of a new species from the Ryukyus, Japan. Zootaxa, 2345: 43-59.

\section{Addresses}

(SJT, HTS) Department of Life Science, National Chung Hsing University, 250, Kuo Kuang Road, Taichung 402, Taiwan; (RN) School of Biology, College of Science, University of Tehran, 14155-6455 Tehran, Iran; (LC) Muséum National d'Histoire Naturelle, 75005 Paris, France.

\section{E-mail address of corresponding author}

(HTS) htshih@dragon.nchu.edu.tw 
Appendix 1. Specimens of the genus Chaenostoma examined.

Chaenostoma boscii. Saudi Arabia: 1 त $(8.8 \mathrm{~mm}), 1$ 우 $(7.0 \mathrm{~mm})$ (NCHUZOOL 13989), Farasan Islands. Egypt: 1 ઈ (not measured) (SMF 26292), Manteqad al-Bahr al Ahmar, coll. C. Rhode and N. Dressler, 6 Sep. 1994.

Chaenostoma sinuspersici. Iran: holotype స (9.1 mm) (SMF 36904), Hormozgan, coll. R. Naderloo, 12 July 2006; 1 우 (not measured) (SMF 38349), Qeshm I., coll. R. Naderloo, 11 May 2008; 1 ઈ (7.5 mm), 1 우 $(8.3 \mathrm{~mm})$ (NCHUZOOL 13988), Gulf of Oman, Iran, coll. S. Ebrahimneged, 21 Jan. 2015. Mayotte: 1 우 $(9.8 \mathrm{~mm})(\mathrm{MNHN}-$ IU-2009-992), coll. J. Dumas et al., 1 Nov. 2009. Djibouti: 2 ๙ measured) (SMF 24496), Ras Siyyan, coll. U. Zajonz and F. Krupp, 24 June 1996.

Chaenostoma crassimanus. Ryukyus, Japan: 1 ठ (6.2 mm), CEL-Oki-124, Okinawa

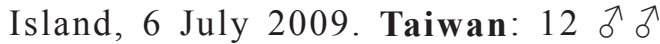
$(2.3-5.6 \mathrm{~mm}), 10$ 우 우 $(2.6-5.2 \mathrm{~mm}$, incl. 6 ovig.), NCHUZOOL 13969, Wushihbi, Taitung, coll. S.-J. Teng et al., 29 July 2014; 1 ठ (3.7 mm), NCHUZOOL 13970, Chenggong, Taitung, coll. S.-J. Teng et al., 28 June 2014; 9 ठ지 (4.1-6.1 mm), 5 우 우 (4.2-5.7 mm), NCHUZOOL 13971, Shanyuan, Taitung, coll. S.-J. Teng et al., 27 July 2014; 6 지 주 (3.9-7.1 mm), 8 우 우 (4.6-7.1 mm), NCHUZOOL 13967, Mudan, Pingtung, S.-J. Teng et al., 25 June 2014; 1 주 $(8.0 \mathrm{~mm}), 1$ 우 $(7.3 \mathrm{~mm}), \mathrm{NCHUZOOL}$ 13968, Mudan, Pingtung, S.-J. Teng et al., 25 June 2014; 1 ઈ (3.4 mm), NTOU 19920110, Jioupeng, Pingtung, coll. J.-F. Huang, 10 June 1992; 1 우 (6.0 mm), ASIZ 70772, Jioupeng, Pingtung, coll. M.-S. Jeng, 10 Dec. 1996; 1 ઈ $(3.0 \mathrm{~mm}), 1$ 우 (3.2 mm), NCHUZOOL 13962, Houwan, Pingtung,

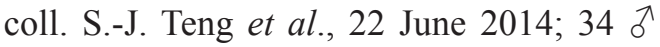
조 (3.2-5.6 mm), 24 우 우 (3.5-5.5 mm), NCHUZOOL 13959, Houwan, Pingtung, coll. S.-J. Teng et al., 26 June 2014; 3 ठ ठ NCHUZOOL 13961, Houwan, Pingtung, coll. L.-G. Tseng, 9 Mar. 2014; 5 ठ $(3.5-4.9 \mathrm{~mm}), 3$ 우 우 $(4.2-4.7 \mathrm{~mm}$, incl. 1 ovig.), NCHUZOOL 13963, Wanlitong, Pingtung, coll. L.-G. Tseng, 29 Apr. 2014; 3 우 우 (5.1-5.5 mm, incl. 2 ovig.), NCHUZOOL 13964, Wanlitong, Pingtung, coll. L.-G. Tseng et al., 16 May 2014; 1 ठ (4.0 mm), 1 우 (4.8 mm), ASIZ 710017 , Nanwan, Pingtung, coll. M.-S. Jeng, 5 Mar. 1997; 1 ठ (5.8 mm), NCHUZOOL 13965 , Daguang Pingtung; 29 ठ え (3.2-5.5 mm), 42 우우 (3.1-6.5 mm), NCHUZOOL 13966, Daguang, Pingtung, coll. S.-J. Teng et al., 24 June 2014; 22 ઈิ $(3.7-5.8 \mathrm{~mm})$, 20 우우 (4.4-6.7 mm, incl. 6 ovig.), NCHUZOOL 13960, Yingueibi, Pingtung, coll. Y.-H. Wang et al., 24 June 2014; 4 ठ స (1.5-3.1 mm), NCHUZOOL 13958, Siaoliuciou, Pingtung, coll. J.-H. Lee et al., 11 Nov. 2013; 1 ઈे (6.1 mm), NTOU 20100527, Lyudao, coll. C.-H. Yang, 27 May 2010; 10 우 우 (4.3-6.7 mm, incl. 2 ovig.), NTOU 20100528b, Lyudao, coll. H.Y. Kuo, 28 May 2010; 4 ઈ ฮ (3.7-4.7 mm), 3 우 우 (3.6-6.1 mm), NTOU, Lyudao, coll. C.-H. Yang, 28 May 2010; 2 えぇ (5.0, $5.3 \mathrm{~mm}), 1$ 우 $(5.7 \mathrm{~mm}), \mathrm{NCHUZOOL}$ 13972, Fengguei, Penghu, coll. S.-J. Teng et al., 1 Sep. 2014; 1 万 (4.6 mm), 3 우 우 (3.8-4.7 mm), NTOU 19900903, Wangan, Penghu, coll. J.-F. Huang, 3 Sep. 1990. Philippines: 1 ठ $(5.3 \mathrm{~mm}), 1$ 우 $(5.5 \mathrm{~mm})$, ZRC M51, Panglao 2004 Expedition, Panglao, Bohol, Philippines, coll. T. Naruse, 2004. New Caledonia: 1 $\precsim(4.9 \mathrm{~mm})$, MNHN-IU-2013-9292, Noumea, coll. J. Poupin and M. Juncker, 5 Mar. 2009; 1 즈 $(6.1 \mathrm{~mm}), 1$ 우 $(7.2 \mathrm{~mm}), \mathrm{MNHN}-$ IU-2009-2591 (= MNHN B32603), coll. J. Poupin, 2009. Mayotte: 2 ठぇ (3.8, $4.9 \mathrm{~mm}$ ), MNHN-IU-2009-993, Bandrele, coll. J. Poupin and R. Cleva, 19 Nov. 2009. Madagascar: $2 \widehat{\delta}(5.4,5.7 \mathrm{~mm}), 2$ 우 
우 (3.8, $6.6 \mathrm{~mm}), \mathrm{MNHN}-\mathrm{IU}-2009-2590$ ( $=$ MNHN B10717), coll. S. Crosnier, Feb. 1962.

Chaenostoma orientale. Taiwan: $1 \delta$ (7.1 mm), NTOU 19891019, Danhai, New Taipei City, coll. J.-F. Huang, 19 Oct. 1989; 1 ठ (9.2 mm), NTOU 20070421, Hemei, New Taipei City, coll. I.-J. Chen et al., 21 Apr. 2007; 1 ठ (9.8 mm), NTOU 20070801a, Hemei, New Taipei City, coll. J.M. Chen, 1 Aug. 2007; 2 ภ ठ (5.6, $6.2 \mathrm{~mm})$, NTOU 20070801b, Hemei, New Taipei City, coll. J.-M. Chen, 1 Aug. 2007; 1 ठ (7.7 mm), NTOU 20070208, Mao-ao, New Taipei City, coll. C.-H. Yang, 8 Feb. 2007; 1 ठ $(6.8 \mathrm{~mm})$, NCHUZOOL, Shanyuan, Taitung, coll. S.-J. Teng et al., 27 July 2014; 1 ठ (4.6 mm), ASIZ 710017, Nanwan, Pingtung, coll. M.-S. Jeng, 5 Mar. 1997; 3 ठ즈 즈 $(4.8-6.8 \mathrm{~mm}), 4$ 우 우 $(6.8-9.2 \mathrm{~mm})$, NTOU 19900905, Jibei, Penghu, coll. J.-F. Huang, 5 Sep. 1990; 10 ठे ठे (4.5-6.9 mm), 3 우우 (5.1-7.6 mm, incl. 2 ovig.), NCHUZOOL 13976, Citou, Penghu, coll. S.-J. Teng et al., 2 Sep. 2014; 1 त (4.1 mm), 6 우우 (4.0-7.3 mm), NCHUZOOL 13977, Watong, Penghu, coll. S.-J. Teng et al., 2 Sep. 2014; 13 재 ठㅈ (4.6-10.3 mm), 10 우우 (3.9-11.0 mm, incl. 6 ovig.), NCHUZOOL 13979, Chihsi, Siyu, Penghu, coll. S.-J. Teng et al., 3 Sep. 2014; 1 ठ (9.7 mm), NCHUZOOL 13980, Chihsi, Siyu, Penghu, coll. S.-J. Teng et al., 3 Sep. 2014; 2 б 주 $(10.7,12.3 \mathrm{~mm}), 1$ 우 $(12.5 \mathrm{~mm})$, NCHUZOOL 13981, Chihsi, Siyu, Penghu, coll. S.-J. Teng et al., 3 Sep. 2014; 1 우 (4.5 mm, juv.), NCHUZOOL 13978, Chihsi, Siyu, Penghu, coll. S.-J. Teng et al., 31 Aug. 2014; 8 중ㅈ (5.7-7.2 mm), 3 우 우 (5.9-6.8 mm, incl. 1 ovig.), NCHUZOOL 13983, Chihdong, Siyu, Penghu, coll. S.J. Teng et al., 31 Aug. 2014; 1 우 (7.7 mm, ovig.), NCHUZOOL 13982, Chihdong, Siyu, Penghu, coll. H.-T. Shih, 18 Oct. 2008; 3 juv. ठิ ठે, NCHUZOOL 13984, Nei-an, Penghu, coll. S.-J. Teng et al., 3 Sep. 2014; 10 万ૈ ત $(3.7-5.2 \mathrm{~mm}), 4$ 우 우 $(4.4-6.9 \mathrm{~mm}$, incl. 1 ovig. 3 juv.), NCHUZOOL 13975, Fengguei, Penghu, coll. S.-J. Teng et al., 1 Sep. 2014; 2 ठ주 $(6.3,8.7 \mathrm{~mm}), 2$ 우 우 $(6.6,10.4 \mathrm{~mm})$, NTOU 19900902 , Fengguei, Penghu, coll. J.-F. Huang, 2 Sep. $1990 ; 4$ 중ㅈ $(6.1-7.5 \mathrm{~mm}), 3$ 우 우 (6.1-10.9 mm, incl. 2 ovig.), NCHUZOOL 13985, Magong, Penghu, coll. Y.-H. Wang et al., 30 Aug. 2014. Indonesia: 19 ठ ठ $(2.5-10.5 \mathrm{~mm}), 12$ 우우 $(4.9-11.3 \mathrm{~mm})$, NCHUZOOL 13987, Bali, coll. H.-T. Shih, 16 July 2014; 2 ๙ठ (not measured) (SMF 5439), Moluccas, Aru Islands, coll. H. Merton, 20 Feb. 1908. Papua New Guinea: 1 ઈ, 1 우 (not measured) (SMF 38539), New Ireland, Ulul Plantation, coll. M. Türkay, 19 July 1998. New Caledonia: 1 ठ (9.1 mm), MNHN-IU-2013-9291, Noumea, coll. J. Poupin and M. Juncker, 5 Mar. 2009. Malaysia: 9 ठठ ठ $(5.7-9.0 \mathrm{~mm}), 18$ 우 우 (5.1-10.4 mm), NCHUZOOL 13986, Tioman, coll. H.-T. Shih, 20 Aug. 2003. 